\title{
Composition and Distribution of Vascular Epiphytes in Different Areas in Obafemi Awolowo, Nigeria
}

\author{
Fatai A. OLOYEDE*, Anthony I. ODIWE, Ayodeji S. OLUJIYAN \\ Department of Botany, Obafemi Awolowo University, Ile-Ife, Nigeria; funsoji@oauife.edu.ng( ${ }^{*}$ correspondingauthor)
}

\begin{abstract}
Composition and distribution of vascular epiphytes were studied in three different areas at Obafemi Awolowo University estate, Nigeria. Each plot, in the selected area, was used for identification of host and epiphytes. Trees were carefully examined. Presence, positions on the host plants and life-forms of all the epiphytes were recorded. Diameter at breast height of the hosts, bark characteristics and height were determined. The climatic data of the areas were measured to determine the relationship between them and epiphytes distributions. Result showed 41 epiphytes belonging to 14 genera and 11 families were identified. Open area had the highest number of epiphytes (22) followed by forest patches (14) then secondary forest (five). The epiphytes were not host specific except epiphytic ferns and Ficus vogelii. Diameter at breast height has effect on the epiphytes distribution and composition. The distribution of epiphytes and environmental factors were lowest in the secondary forest. Moraceae was the most dominant host family (44.8\%) while Nephrolepis undulata and Nephrolepis biserrata were the most common species of epiphytes. Most epiphytes preferred sub-canopy level, few occurred in the canopy level but none at emergent level. Climatic factors, diameter at breast height and bark characteristics of the host plants are useful in determining compositions and distributions of these epiphytes.
\end{abstract}

Keywords: biomass, climatic factors, host plants, identification

\section{Introduction}

Epiphytes are plants that are rooted and grow on the trunks and branches of trees and shrubs for at least part of their life cycle for the purpose of support. Classes of epiphytes include those that spend their entire lives on the host plants which are referred to as total epiphytes or holoepiphytes. Those that are initially terrestrial and later became epiphytic having lost their contact with the soil, are referred to as partial epiphyte or home-epiphytes and those that are initially epiphytes and later became terrestrial, having been rooted in the soil (Dutta, 2005). Epiphytes are important elements of many tropical ecosystems and they are abundant in the tropical rain forest, dry forest and semiarid shrub lands (Mondragón et al., 2004). Their important ecological roles in both primary and secondary forests include acquisition of nutrients directly from the atmospheric sources and indirectly from soil-rooted sources (Benzing, 1990). They also provide animals with shelter (Nadkarni and Matelson, 1989). Epiphytes abound in both lowland and sub-montane forests in different parts of the world. In Australia (Burges and Johnston, 1953), Liberia and Old World (Johansson, 1974), Nigeria (Sanford, 1969) Asia (Went, 1940) epiphytes were considered as component of a general vegetation compositions. Studies of epiphytes compositions and distributions are available in secondary forests (Yeaton and Gladstone, 1982). Epiphytes biomass, comparison and distribution in montane and primary forests have been reported (Coxson and Nadkarni, 1995).

Many epiphytes have habitat preferences especially towards large trees which influence their distributions. This is due to the ability of large trees to accommodate dispersing seeds and because crowns of large trees may be cooler and more ventilated than those of smaller trees due to generally higher wind speed in the upper parts of the canopy (Bernai et al., 2005; Hernández-Rosas, 2003; Rey and Alcantara, 2000). Some epiphytes establish more successfully on particular host species and in specific microsites within the host crowns (García-Suárez et al., 2003; Mondragón et al., 1999; Mondragón et al., 2004). Little attention has been paid on the epiphytes of lowland secondary forest as compared to other growth forms (trees, shrubs and herbaceous) in Nigeria. There is the need to fill the gaps about the compositions and distributions of epiphytes in Nigeria, particularly in lowland rainforest like Ile-Ife in order to document the distributions and the interactions of the epiphytes with the host and environmental factors. Therefore, this study focused on the critical survey and identification of vascular epiphytes with the aim of providing information on the compositions and distributions of the epiphytes in relation to their host specificity, girth size, host tree height and climatic factors. 


\section{Materials and methods}

\section{Study area}

The study sites were located within the Obafemi Awolowo University estate, situated in Ile-Ife, Nigeria. This area used to be a very thick primary forest which has been destroyed over the years to become secondary forest and derived savanna. Most of the forests have been replaced by tree crop plantations and farm land. Ile-Ife is situated within the rainforest zone and the study sites were located on latitude $7^{\circ} 32^{\prime} \mathrm{N}$ and longitudes $4^{\circ} 32^{\prime} \mathrm{E}$ within Ile-Ife. The elevation of the area ranges from 276 to $286 \mathrm{~m}$ above sea level. The two prominent seasons in Ife area are the rainy and dry seasons. The rainy season lasts from mid-March to late October and the rainfall is bimodal with peak periods in July and September. The annual rainfall is $1400 \mathrm{~mm}$. The dry season lasts from November till March and the annual temperature ranges from $27-34^{\circ} \mathrm{C}$ with the highest experienced in the dry season (Oke and Isichei, 1997). Most soils in this area have been classified as Alfisol and Ultisol (Soil Survey Staff, 1990). They are formed from old parent materials which have been subjected to intensive weathering and leaching with predominant kaolinite clay having low cation exchange capacity and less exchange sites, hence they are considered deficient in most plant nutrients (Wassel, 1969). The forest sub-type is dry-deciduous forest (Onochie, 1979).

\section{Sampling methods}

Reconnaissance field survey was first undertaken across the University estate to certain different vegetation types found within this estate. The study area was divided into secondary forests, forest patches and open area of $100 \mathrm{~m} \mathrm{x}$ $100 \mathrm{~m}$ plots.

The sampling was carried out between January and July 2011 from various locations at Obafemi Awolowo University estate, Ile-Ife. Field surveys were carried out to explore the composition and distribution of the vascular epiphytes in the above mentioned areas. A total of one hectare of plot was marked out in each area. In the enumeration, epiphytes and their host species were identified. The DBH trees of all the phorophytes (host) was measured and used to obtain the basal area of the host. Their bark characteristics (texture and peeling behaviors) were also noted. The height of the host was determined to evaluate if they were sub-canopy $(\leq 21 \mathrm{~m})$, canopy level $(21$ $\mathrm{m})$ and or emergent canopy $(\geq 40 \mathrm{~m})$. The environmental data like elevation, humidity and temperature of the microhabitat were measured and recorded.

\section{Results and discussion}

\section{Virus survey}

The present study showed a total number of 41 epiphytes belonging to 28 species, 21 genera and 12 families. Forest patches had the highest number of epiphytes (22 individuals), followed by open habitat (14 individuals) and secondary forest (five individuals) (Tab. 1).

Epiphytes were hosted on a total of nine, five and four tree species in the forest patches, secondary forest and open habitats respectively. This showed that 18 host trees and 41 epiphytes were recorded in this study. Ficus spp which belongs to the family Moraceae occurred as the most common epiphyte on many host species while

Hyphaene thebaica and Afzelia africana had the highest number of epiphytes across the study area (Tab. 1).

Tab. 1. Composition and distribution of host and epiphytes across the study locations at the Obafemi Awolowo University, Ile-Ife, Nigeria

\begin{tabular}{|c|c|c|c|c|c|}
\hline \multicolumn{2}{|c|}{ Forest patches } & \multicolumn{2}{|l|}{ Secondary forest } & \multicolumn{2}{|c|}{ Open habitat } \\
\hline Host plant & $\mathrm{NOE}$ & Host plant & NOE & Host plant & $\mathrm{NOE}$ \\
\hline Afzelia africana & 6 & Celtiszenkeri & 1 & Alstoniaboneii & 4 \\
\hline Delonix regia & 4 & Dracaena fragrans & 1 & Acacias spp & 2 \\
\hline Peltophorum spp & 3 & Holarrhenafloribund & 1 & $\begin{array}{c}\text { Canthium } \\
\text { vulgare }\end{array}$ & 2 \\
\hline \multirow[t]{6}{*}{ Elaeis guinensis } & 1 & L. cupanoides & 1 & Dracaenamanii & 1 \\
\hline & & Elaeis guinensis & 1 & $\begin{array}{c}\text { Hyphaene } \\
\text { thebaica }\end{array}$ & 6 \\
\hline & & & & Keetia vulgare & 1 \\
\hline & & & & $\begin{array}{c}\text { Magaritaria } \\
\text { discoidia }\end{array}$ & 1 \\
\hline & & & & Millicia excelsa & 2 \\
\hline & & & & Elaeis guinensis & 3 \\
\hline Total & 14 & & 5 & & 22 \\
\hline $\begin{array}{c}\text { NOE: no of } \\
\text { epiphyte; }\end{array}$ & & L: Lecaniodiscus & & spp: species & \\
\hline
\end{tabular}

\section{Canopy type}

Out of the 41 epiphytes encountered across the study sites, $83 \%$ of them occurred at a tree height of less than $21 \mathrm{~m}$ (sub-canopy) and only $18 \%$ occurred between $21 \mathrm{~m}$ and 40 $\mathrm{m}$ (emergent) (Fig. 1).

\section{Distribution of epiphytes on host species}

The trunk of the host trees had the highest number of epiphytes followed by the crown and then the base of the trunk (Fig. 2). The epiphytes were found mostly on the base in the forest patches and open habitat while in the secondary forest they were found on the stem (Fig. 2). Ficus vogelii and Nephrolepis biserrata were mostly found on Elaeis guinensis. The two main groups of epiphytes identified in this study were stranglers and non-stranglers (Fig. 3 and 4). Most of the epiphytes that are stranglers are known to kill their host with time and become established as independent trees.

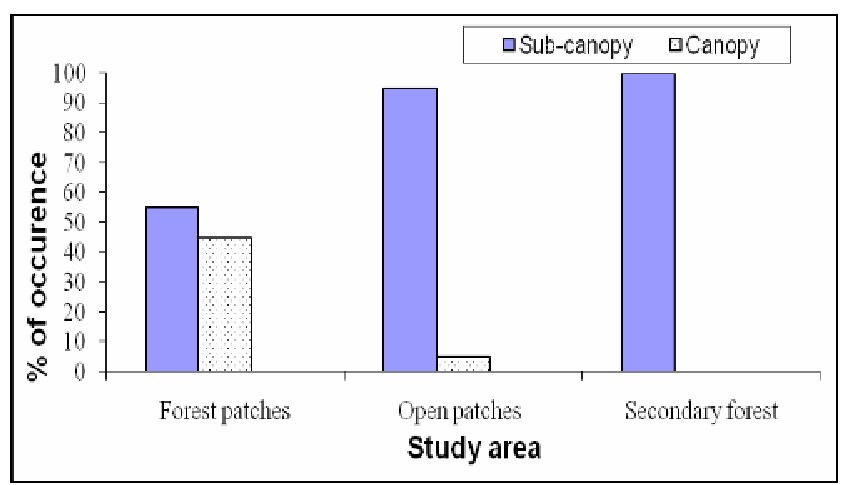

Fig. 1. Distribution of epiphytes into canopy, sub-canopy and emergent across the study sites at Obafemi Awolowo University, Ile-Ife 
318

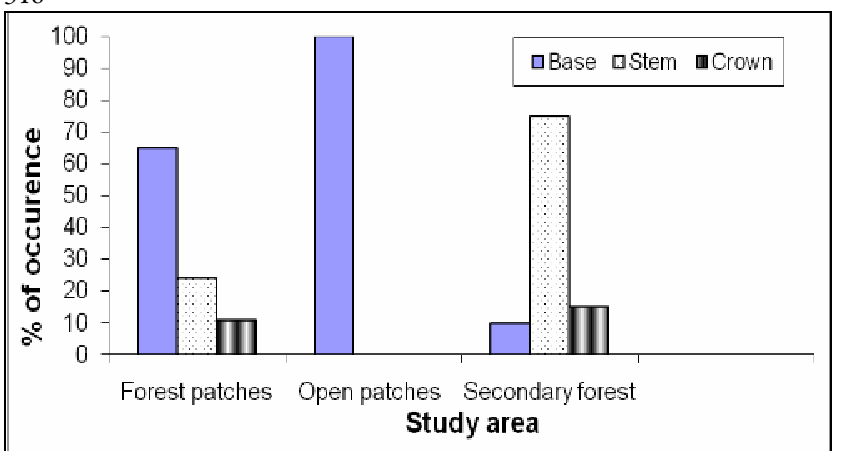

Fig. 2. Distribution of epiphytes on different point on the host species across the study sites at Obafemi Awolowo University, Ile-Ife

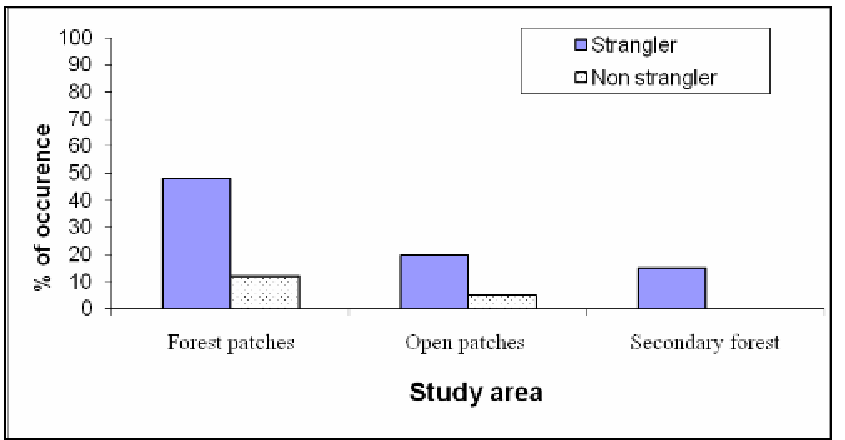

Fig. 3. Distribution of epiphytes into strangler and nonstranglers across the study sites
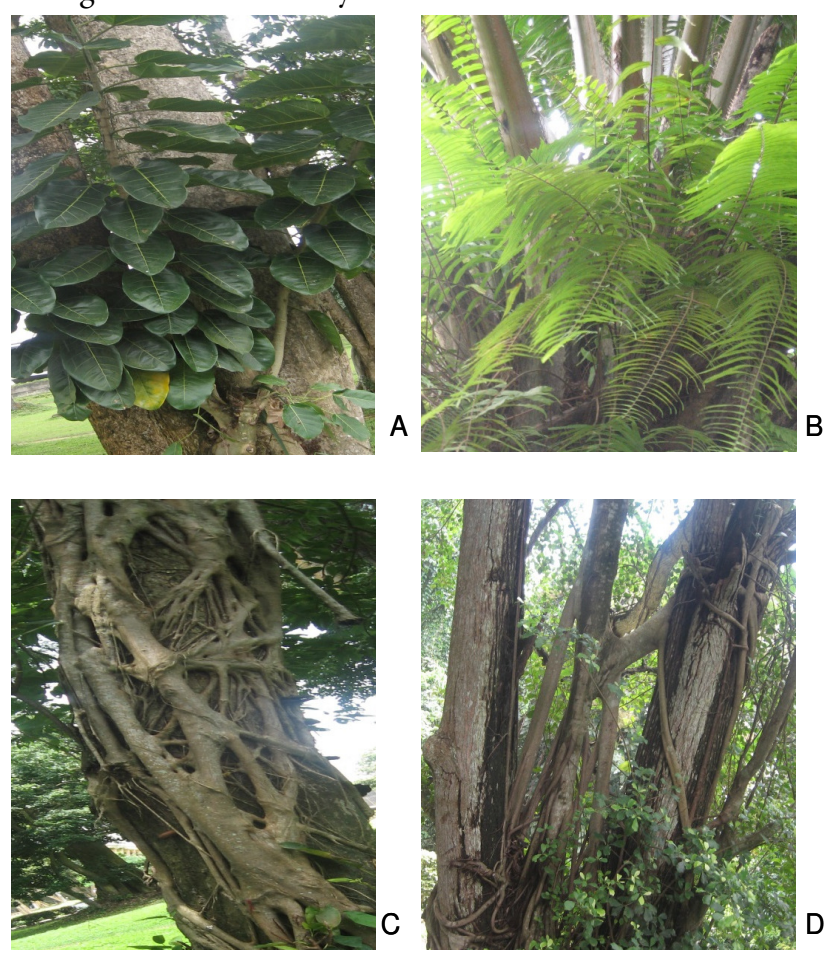

Fig. 4. Epiphytes and host trees showing different point of attachments and nature of the epiphytes.

A: Ficus vogelii (strangler epiphyte) on the Sapthodea campanulata

B: Nephrolepis biserrata (non-strangler epiphyte) on Elaeis guinensis

C: Ficus vogelii (strangler epiphyte) on the Sapthodea campanulata

D: Ficus vogelii (strangler epiphyte) on the Sapthodea campanulata (stranglated the host to death)

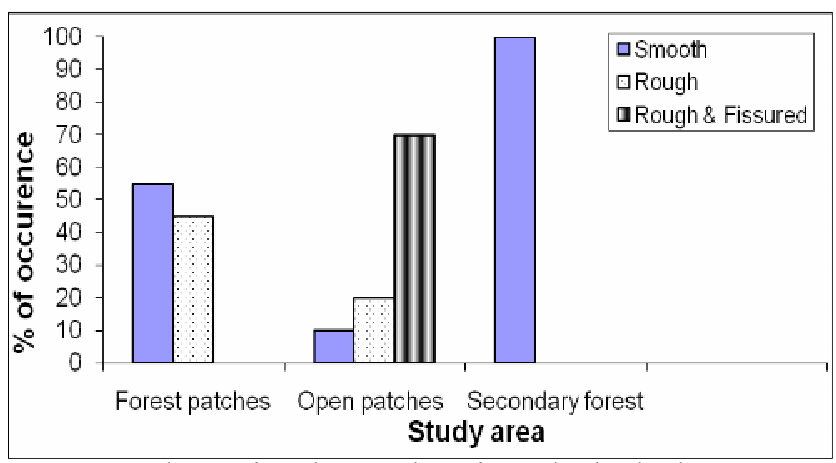

Fig. 5. Epiphytes distribution based on the bark characteristic across the study sites

The diameter at breast height (DBH) and bark characteristics

Results from this study showed that most of the epiphytes were found on the bigger DBH trees $(\mathrm{DBH}>$ $100 \mathrm{~cm}$ ). Out of the 41 epiphytes encountered, only five or $12 \%$ were found on host trees with $\mathrm{DBH}$ less than $100 \mathrm{~cm}$ while the rest were found on bigger DBH (36 or $88 \%$ ). It should be noted that the secondary forest site generally had much more numbers of smaller DBH trees. Most of the epiphytes in the open habitat were found on rough and fissured bark while in the secondary forest, all the epiphytes were on smooth bark (Fig. 5).

The high number of epiphytes (22) found in the forest patches in this study indicate that this habitat may be the most suitable place out of the different areas studied for the growth of these epiphytes. This result is similar to the findings of Levin and Mathieson (1991) who reported that epiphyte populations are highly dependent on the distribution and abundance of suitable substrata. The influence of bark characteristics on the epiphytes distribution as observed in the different study areas in this study showed the importance of the structure and porosity or the three barks accumulation of humus on the distribution of vascular epiphytes. This observation is consistent with the result of Brown (1990), who reported that host trees with scabrous barks support more epiphytes. Kerman and Fowler (1995), Steege and Cornelissen (1989), Zimmerman and Olmsted (1992) also reported that the bark texture influences the distribution of epiphyte.

The presence or absence of epiphytes could be used as an important indicator of the stage of succession in the lowland rain forests in that less number of epiphytes were recorded at the secondary forest which was less disturbed compared with more epiphytes that were found at the forest patches and open habitat that were continuously disturbed. This is in agreement with the findings of Richter (1991) who reported that age and disturbance played major roles in changing the structure and occurrence of vascular epiphytes because they are very sensitive to direct solar radiation and changes in climatic conditions.

The fate of the epiphytes is directly related to the fate of the host trees and hence there can be no epiphytes without supporting structures. Went (1940) reported differences between epiphyte flora on different species of phorophytes, physical factors of the host, chemical differences in the bark and the stem flow water as crucial in determining the presence or absence of the epiphytes. 
The lower number of epiphytes and their occurrence at lower DBH in the secondary forest are usually related to the age of the plants. Therefore, young trees are usually under cover in the closed forest, as a result, they receive limited light and this might have accounted for the lower number of epiphytes recorded in the secondary forest. As they grow, the vegetative parts (trunk, shoots and branches) get larger enough to provide sites for epiphytes to attach and at the same time leaf cover reduces light penetration to the subcanopy levels.

The occurrence of more epiphytes on bigger trees recorded in this study is in line with the findings from other studies, where different forest ecosystems have shown that epiphyte diversity increases with tree size (Johansson et al., 2007; McCune, 1993). Munoz et al. (2003) also showed that larger trees hold more epiphyte species in Chilean North Patagonian forests. This pattern has been explained on the basis that bigger trees offer a larger area and more microhabitats are expected to have larger numbers of epiphytes (Annaselvam and Parthasarathy, 2001; FloresPalacios and Garcia-Franco, 2006). Therefore, large trees can be a very important element for the conservation of forest biodiversity (Berg et al., 1994). Several studies have suggested that tree size plays important roles in the composition of epiphytes in the forests (Burns and Dawson, 2005; Lyons et al., 2000; Zotz and Vollrath, 2003).

The fact that most of the epiphytes were found in the sub-canopy level highlights significant ecological impacts. The preference to the sub-canopy level, indeed, has become an important adaptation to minimize water loss through evapo-transpiration and therefore maximize the little moisture trapped in the debris. Nevertheless, being in subcanopy level is also not good for the epiphytes because of the lack of light for maximum photosynthetic process. This might have accounted for lower number of epiphytes encountered in the secondary forest.

\section{Conclusions}

The predominance of the epiphytes in the open and forest patches compared to the secondary forest shows that the habitat played a major role in the distributions of these epiphytes. It is clear from this study that Ficus vogelii and Nephrolepis biserrata are host specific in that most of them are found on the Elaeis guinensis. Trees with a high diversity of attachment sites, rough or fissured bark are more likely to contribute to the conservation of epiphytes in the forest. Climatic variables were also influence the distribution of these epiphytes.

Generally, epiphytes play crucial roles in the rain forest ecosystem and therefore the understanding and knowledge of their distribution and conservation in the plant ecosystem cannot be over-emphasized. Keeping track of the changes in any epiphyte community through ecological monitoring is an important aspect of tropical rain forest management that could provide clues on ecological changes that are taking place within the forest ecosystem. It is hoped that this article will help to highlight the importance of epiphytic flora of the area and also serve as baseline data for further research in this field.

\section{References}

Annaselvam J, Parthasarathy N (2001). Diversity and distribution of herbaceous vascular epiphytes in a tropical evergreen forest at Varagalaiar, WesternGhats, India. Biodivers Conser 10:317329.

Bernai R, Valverde T, Hernández-Rosas L (2005). Habitat preference of the epiphyte Tillandsiare curvata (Bromeliaceae) in a semi-desert environment in Central Mexico. Can J Bot 83:128-1247.

Benzing DH (1990). Vascular epiphytes. General Biology and related biota. Cambridge University Press, Cambridge, UK.

Berg A, Ehnstro“m B, Gustafsson L, Hallingba“ck T, Jonsell M, Weslien J (1994). Threatened plant, animal and fungus species in Swedish forests: distribution and habitat associations. Conser Bio 8:718-731.

Brown DA (1990). El epifitismo en lasselvas montanas del Parque Nacional "El Rey" Argentina: Composición florística y padrón de distribución. Rev Biol Trop 38:155-166.

Burges A, Johnston RD (1953). The Structure of a New South Wales Subtropical Rainforest. J Ecol 41:72-83.

Burns KC, Dawson J (2005). Patterns in the diversity and distribution of epiphytes and vines in a New Zealand forest. Aust J Ecol 30:883-891.

Coxson DS, Nadkarni NM (1995). Ecological roles of epiphytes in nutrient cycles of forest ecosystems, Pp. 495-543. In Lowman MD, Nadkarni NM (Eds.). Forest canopies. Academic Press, California.

Dutta AC (2005). Botany for Degree Students, Pp. 1-326. $6^{\text {th }}$ Edition. Oxford University Press, India.

Flores-Palacios A, Garcia-Franco JG (2006). The relationship between tree size and epiphyte species richness: testing four different hypotheses. J Biog 33:323-330.

García-Suárez MD, Rico-Gray V, Serrano H (2003). Distribution and abundance of Tillandsia spp. (Bromeliaceae) in the Zapotitián valley, Puebla, Mexico. Plant Ecology 166:207-215.

Hernández-Rosas L (2003). Patrón de germinacióon y establecimiento de plántulas de Tillandsia recurvata: uncontribución al studio de sudinámica metapoblacional. B.Sc. Thesis submitted to the Faculty of Sciences, National autonomous University, Mexico.

Johansson D (1974). Ecology of vascular epiphytes in West African Rainforest. Acta Phytogeogr Suecica 59:1-129.

Johansson P, Rydin K, Thor G (2007). Tree age relationships with epiphytic lichen diversity and lichen life history traits on ash in southern Sweden. Ecosci 14:81-91.

Kernan C, Fowler N (1995). Differential substrateuse by the epiphytes in Corcovado National Park, Costa Rica: a source of guild structure. J Ecol 83:65-73.

Levin PS, Mathieson AC (1991). Variation in a host-epiphyte relationship along a wave exposure gradient. Mar Ecol Pro Ser 77:271-278.

Lyons B, Nadkarni NM, North MP (2000). Spatial distribution and succession of epiphytes on Tsugaheterophylla(western hemlock) in an old-growth Douglas-fir forest. Can. J Bot 78:957-968. 
320

McCune B (1993). Gradients in epiphyte biomass in three Pseudotsuga-Tsuga forests of different ages in western Oregon and Washington. The Bryol 96:405-411.

Mondragón D, Durán R, Ramíres I, Olmsted I (1999). Population dynamics of Tillandsiabrachyacaulos Schitdl. (Bromeaceae) in Dzibilchaltum National Park, Yucatán. Selb 20:250-255.

Mondragón D, Durán R, Ramíres I, Ververde T (2004). Temporal variation in the demography of the clonal epiphyte Tillandsiabrachycaulos (Bromeliaceae) in the Yucatán Penninsula, Mexico J Trop Ecol 20:1-20.

Munoz AA, Chacon P, Perez F, Barnert ES, Armesto JJ (2003). Diversity and host tree preferences of vascular epiphytes and vines in a temperate rainforest in southern Chile. Aust J Bot 51:381-391.

Nadkarni NM, Matelson TJ (1989). Bird use of epiphyte resources in Neotropical trees. Cond 91:891-907.

Oke SO, Isichei AO (1997). Floristics and structure of the fallow vegetation in Ile-Ife area of Southwestern Nigeria. Nig J Bot 10:37-50.

Onochie CFA (1979). The Nigerian Rainforest ecosystem: An overview, p. 1-13. In: Okali, D.U.U. (Ed.). The Nigerian Rainforest ecosystem, proceedings of the Man and Biosphere on the Nigerian Rain Forest Ecosystem, University of Ibadan Conference Centre, 24-26 January. Nigerian MAB committee, Ibadan.

Rey PJ, Alcantara JM (2000). Recruitment dynamics of a fleshyfruited plant (Oleaeuropea): connecting patterns of seed dispersal to seedling establishment. J Ecol 88:622-633.

Richter M (1991). Methoden der Klimaindikationdurchpflanzenmorphologische Merkmale in den Kordilleren der Neotropis. Die Erde 122(4):267-289.
Sanford WW (1969). The Distribution of Epiphytic Orchids in Nigeria in Relation to each other and Geographic Location, Climate, type of Vegetation and tree species. Biol. J Linn Soc $1: 247-285$.

Soil Survey Staff (1990) Soil Taxonomy: A Basic System for Classification, Mapping and Interpreting Soils. USDA Soil Conservation Services, Washington DC.

Steege H, Cornelissen JHC (1989). Distribution and ecology of vascular epiphytes in lowland rain forest of Guyana. Biotrop 21:331-339.

Wassel M (1969). Cocoa soils in Nigeria, pp. 417-429. In: Proceedings of Second International Cocoa Research Conference, Brazil.

Weaver PL, Murphy PG (1990). Forest structure and productivity in Puerto Rico's Luquillo Mountains. Biotrop 22:69-82.

Went FW (1940). Soziologie der EpiphyteneinesTropischenUrwaldes. Annl J Bot Buitenz 50:1-98.

Yeaton RI, Gladstone DE (1982). The pattern of colonization of epiphytes on calabash trees (Crescentia alata) Costa Rica Biotrop 14:137-140.

Zimmerman JK, Olmsted IC (1992). Host Tree utilization $n$ by vascular epiphytes in a seasonally inundated forest (Tindal) in Mexico. Biotrop 24:402-407.

Zotz G, Vollrath B (2003). The epiphyte vegetation of the palm Socrateaexorrhiza-correlations with tree size, tree age and bryophyte cover. J Trop Ecol 19:81. 